\title{
OLD PROMISES: THE JUDICIARY AND THE FUTURE OF NATIVE AMERICAN FEDERAL ACKNOWLEDGMENT LITIGATION
}

\author{
Alva C. MATHER
}

\section{INTRODUCTION}

The United States government has "'moral obligations of the highest responsibility"' to the four million American Indians" and Alaska Natives residing in the United States. ${ }^{3}$ The federal government, however, presently only honors its fiduciary duty to a portion of the current Indian population.

Today, Native American tribes are divided into two categories: those recognized by the federal government, and those not formally "recognized" by the United States. Tribes that are federally recognized receive the benefits and services exclusively reserved by the federal government for those classified as Indians. As a result of historical circumstances, nonrecognized tribes are excluded from federal assistance because they have not maintained a formal relationship with the United States. Denied their status as "Indians," members of nonrecognized tribes have sought the assistance of the federal judiciary to compel the federal government to comply with its trust obligations to all Native Americans. Courts have struggled to decide "whether and to what extent old promises should be honored" to Indian tribes, ${ }^{4}$ a question made more difficult when considered as to tribes not recognized by the federal government.

${ }^{1}$ Cobell v. Norton, 240 F.3d 1081, 1099 (D.C. Cir. 2001) (quoting Seminole Nation v. United States, 316 U.S. 286, 297 (1972)).

${ }^{2}$ Throughout this Comment, I will use the terms "Native American," "American Indian," or "Indian" interchangeably. Although the politically correct term has been "Native American," native people often refer to themselves as "Indians." See, e.g., About $N A R F$, Native Am. Rights Fund, at http://www.narf.org/intro/index.html (last visited Apr. 17, 2003) (describing the Native American Rights Fund as a "non-profit organization that provides legal representation and technical assistance to Indian tribes" (emphasis added)); see also VINE DELORIA, JR., CUSTER DIED FOR YOUR SINS: AN INDIAN MANIFESTO (1969) (using the term "Indian" throughout the book to refer to the aboriginal inhabitants of North America).

${ }^{3}$ Stella U. Ogunwole, The American Indian and Alaska Native Population: 2000 (2002), available at http://www.census.gov/prod/2002pubs/c2kbr01-15.pdf.

${ }^{4}$ CHARLES F. WILKINSON, AMERICAN INDIANS, TIME, AND THE LAW 4 (1987). 
In Part I, I begin the analysis of federal recognition litigation by examining the historical circumstances surrounding the category of "nonrecognized" tribes and outlining the economic and emotional benefits associated with federal recognition. In Part II, I discuss the administrative process by which nonrecognized tribes may become recognized and the specific hardships associated with the process. In Part III, I examine the federal judiciary's response to the litigation efforts of nonrecognized tribes. Although federal courts have pervasively used procedural barriers to judicial review in order to avoid reaching the substantive claims of nonrecognized tribes, recent successful mandamus suits suggest that there is hope for nonrecognized tribal litigants.' Finally, in Part IV, I discuss the possible extrajudicial impact of the mandamus suits and their relevance to the future of federal recognition litigation.

\section{Federal ReCOGNITION}

"Federal recognition" is the legal term of art used to identify those Native American tribes with which the United States government acknowledges a formal government-to-government relationship. Recognized tribes have access to the rights and privileges reserved exclusively for Indians." Tribes that do not have an official relationship with the United States are called "nonrecognized tribes." To appreciate the particular social situation and legal struggles of nonrecognized tribes, it is important to be familiar with the historical circumstances which led to the creation of these categories and understand the rights and benefits currently associated with recognized status.

\section{A. The Historical Development of the Nonrecognized Indian Tribe}

Nonrecognized tribes are tellingly referred to as the "forgotten people,"7 or "lost tribes." looked by federal officials. Instead, they were historically excluded

"See infra Part III.B (summarizing recent federal court victories by two nonrecognized tribes seeking recognition by the United States).

"See infra Part I.B (surveying the federal benefits contingent on formal recognition of an Indian tribe by the United States government).

${ }^{7}$ Frank W. Porter, III, An Historical Perspective on Nonrecognized American Indian Tribes, in NONRECOGNIZED AMERICAN INDIAN TRIBES: AN HISTORICAL AND LEGAL PERspective 1, 43 (Newberry Library Ctr. for the History of the Am. Indian, Occasional Papers Series No. 7, 1983).

${ }^{8}$ Susan D. Greenbaum, In Search of Lost Tribes: Anthropology and the Federal Acknowledgment Process, 44 HUM. ORG. 361,362 (1985). 
from the federal-Indian relationship because: (1) they hid from United States officials after being forced to leave their homelands; (2) they were expressly excluded from Indian reorganization efforts in the 1930s; or (3) their relationship with the United States was expressly terminated by legislative action.

\section{Indian Removal}

Prior to the 1830s, Native Americans inhabited land across the continental United States. In 1830, President Jackson negotiated the removal of eastern Indian tribes to lands west of the Mississippi River." Through force and coercion, eastern tribes were moved to reservations in Arkansas, Kansas, Illinois, and sometimes as far as the Oklahoma Territory." Known as the "Trail of Tears," the journey west killed many Native Americans through exposure or just "plain heartbreak." Although there was no explicit governmental action to remove Indians on the west coast, when gold and other valuable natural resources were discovered, western tribes were likewise forced to leave their homes and move onto reservations. ${ }^{12}$ At the time, the United States government assumed that the majority of Native American families would obey the federal removal effort and amicably displace themselves to the reservations. ${ }^{13}$ Many Indians decided not to leave their homes and hid instead.

Believing that "federal policies would be harmful to their tribes... [and] that [f] ederal agents were corrupt," these tribes developed communities where the natural conditions provided means of shelter and distance from the outside world. ${ }^{14}$ A number of tribes built villages on or near "swamps [or] barren lands" in order to avoid

"See, e.g., A Treaty of Perpetual Friendship, Cession and Limits, 7 Stat. 333, 333-34 (1830) (negotiating the relocation of the Choctaw Nation to lands west of the Mississippi river).

1" See Steven L. Pevar, The Right's of Indians and Tribes: The Basic aClU Guide TO INDIAN AND TRIBAL RIGHTS 4 (2d ed. 1992) (describing the geographic spread of the westward relocation of eastern Indian tribes).

11 ANGIE DEBO, A HiSTORY OF THE INDIANS OF THE UNITED STATES 118 (1970).

12 See PEvar, supra note 10, at 4 ("The discovery of gold in California in 1848 brought thousands of settlers to the West and increased the desire for Indian land.").

${ }^{13}$ But cf., DEBO, supra note 11 , at 119 (discussing the dire consequences for those Creek Indians who did not remove with the rest of their tribe to Oklahoma).

I4 See Am. Indian Policy Review Comm'n, Final Report 465 (Comm. Print 1977) (recounting that certain tribes chose hiding and isolation in the face of policies they deemed harmful). 
contact with federal officials." In a very real sense, "[s] ecrecy meant survival" for these tribes. ${ }^{16}$ For them to have been identified by the federal government as Native Americans "would have been for them to die."

While in hiding, many of these tribes intermarried with other races in the surrounding area. Intermarriage was necessitated by the tribes' desire to remain hidden from the federal government, as well as a way to compensate for the lack of available marriage partners. ${ }^{\text {I8 }}$ Through intermarriage, these tribes were able to retain their Indian customs while appearing as members of other races to governmental officials. For instance, many California Indians were mistakenly identified as Mexicans by census takers. ${ }^{19}$ Likewise, eastern Indians were "perceived by Whites as mulattoes, mestizos, mixed-bloods, or tri-racial isolates." ${ }^{20}$ The federal government has often used the intermarriage of Indian tribes as evidence of their assimilation into white culture. In reality, intermarriage was an explicit survival tactic which allowed Indian tribes "to maintain their identity.",

Whereas Indian tribes that hid from governmental entities made an affirmative decision to sever their ties with the United States government, other tribes were explicitly denied the opportunity to form a relationship with the United States during the Indian sovereignty efforts of the 1930s.

\section{The İndian Reorganization Act}

One of the most significant periods in federal-Indian policy began with the 1934 passage of the Indian Reorganization Act (IRA). ${ }^{22}$ The purpose of the IRA was to foster Indian self-sufficiency by rehabilitat-

15 Porter, supra note 7 , at 23.

${ }^{16}$ Id.

17 Federal Acknowledgment Process: Hearing Before the Select Comm. on Indian Affairs, 96th Cong. 2 (1980) (statement of LaDonna Harris, President, Americans for Indian Opportunity).

I8 See James Clifford, The Predicament of Culture: Twentieth-Century ETHNOGRAPHY, LITERATURE, AND ART 297 (1988) (noting that the nonrecognized Mashpee tribe intermarried with blacks due, in part, to "a relative shortage of men among the Indians and of women among the blacks").

19) Charles W. Blackwell \& J. Patrick Mehaffey, American Indians, Trust and Recognition, in NONRECOGNIZED AMERICAN INDIAN TRIBES: AN HISTORICAL AND LEGAL PersPeCTIVE, supra note 7 , at 50,62.

${ }^{20}$ Porter, supra note 7 , at 7 .

21 ld. at 24.

${ }^{22} 48$ Stat. 984 (1934) (codified as amended at 25 U.S.C. $\$ \$ 461-494(2000)$ ). 
ing their economic status and providing the opportunity to become federally chartered corporations. ${ }^{2.3}$ From 1934 to 1953, Indian land was returned, new land was purchased and developed as reservations, and a ten-million-dollar revolving credit line was established for participating tribes. ${ }^{24}$

Though the purpose of the IRA was to provide federal assistance to "Indian tribes" generally, many tribes were not asked to participate in the reorganization efforts. While some tribes decided to "opt out" of the IRA in order to escape federal supervision and surveillance," many were intentionally excluded. ${ }^{26}$ For example, one tribe was excluded because its members had "radios in their homes"; the federal government reasoned that having radios in one's home suggested that these people were "too civilized" to be legitimate Indians." In the end, ninety-nine tribes were organized under the IRA and ninety-six Indian tribes were excluded. ${ }^{28}$ All of the tribes that organized became federally recognized tribes, and those that did not remained nonrecognized tribes.

The 1930s and 1940s were a time of governmental support for Indian sovereignty. Federal policy, however, took a drastic turn in the 1950 s when the federal government terminated its relationship with hundreds of Indian tribes.

\section{The Termination Period}

Historically, treaty negotiations were the "accepted method" for establishing a legal relationship between an Indian tribe and the United States government. ${ }^{2 !}$ By signing a treaty, the United States

${ }^{23}$ See PEVAR, supra note 10, at 6 (observing that the IRA was designed to encourage tribal organization as federally chartered corporations).

${ }^{24}$ See id. (recognizing the IRA's creation of a "revolving credit fund from which loans could be made to incorporated tribes").

25 See Carole Coldberg-Ambrose, Of Native Americans and Tribal Members: The Impact of Law on Indian Group Life, 28 I.AW \& SoC'Y REV. 1123, 1133 (1994) (explaining that some tribes selected out of the IRA "to escape its strictures").

${ }^{2 t i}$ See Indian Federal Acknowledgnent Process: Hearing on H.R. 3430 Before the House Comm. on Interior $\mathcal{F}^{2}$ Insular Affairs, 102 d Cong. 69 (1992) [hereinafter Hearing on H.R. 3430] (statement of Bud Shepard, Former Bureau of Indian Affairs Employee) (declaring that some tribes were deliberately ignored for failing to satisfy "some unwritten, subjective criteria established within the [Bureau of Indian Affairs]")

\footnotetext{
${ }^{27}$ Id.

28 Id. at 90 (statement of Ken Tollefson, Anthropologist, Seattle Pacific University).

29) PEVAR, supra note 10 , at 37 .
} 
recognized both the sovereignty of Indian tribes and the government's responsibility to protect federal Indian land and provide needed goods and services. ${ }^{30}$ Indian treaties provide the greatest legal protection for tribal rights given that these "treaties have the same force and effect as federal statutes," and thus "[a] violation of an Indian treaty is a violation of federal law." Without a recognized treaty, Indian tribes are vulnerable to the loss of sovereignty recognition and federal services.

In 1953, Congress adopted House Concurrent Resolution 108, which sought to end the provision of federal services and benefits to Native Americans "at the earliest possible time." "3: The federal government officially terminated its relationship with over one hundred tribes and granted states extensive jurisdiction over Indian territories." Many tribes that were fortunate enough to have signed a treaty with the United States suddenly found themselves unrecognized as Native Americans. In California, for example, forty-one Indian tribes had their relationship with the federal government terminated. ${ }^{34}$

The historical background of nonrecognized tribes varies from tribe to tribe and region to region. In addition to removal, the IRA, and termination of federal assistance, colonial wars so weakened some groups that they were simply overlooked by United States officials. ${ }^{35}$ Whatever the historical circumstances that led to their modern situation, all nonrecognized tribes are denied the federal rights, privileges, protections, and status afforded federally recognized tribes.

\section{B. Legal Privileges for "Indians"}

Federal recognition provides three main advantages to Native American tribes. The first is the federal government's acknowledgment of Indian sovereignty. The second is the receipt of federal serv-

31) Id. at $37-43$.

31 Id. at 43 .

32 l. at 7.

33. Sid. (describing Congress's termination of federal tribal assistance and, "[i]n an effort to reduce federal responsibilities even further," its conferral of "full criminal and some civil jurisdiction" over Indian reservations to designated states).

${ }^{34}$ Rachael Paschal, Comment, The Imprimatur of Recognilion: American Indian Tribes and the Federal Acknowuledgment Process, 66 WASH. L. REV. 209, 214 (1991).

3e Porter, supra note 7 , at 5 (indicating that some tribes, weakened and depopulated by "dealing with colonial governments," were overlooked by federal officials charged with "resolving the agreements that former European nations had made with individual Indian tribes"). 
ices and protections by eligible tribes. The final advantage is the prestige and honor associated with federally recognized status.

\section{Tribal Sovereignty}

Recognition of tribal sovereignty is at the heart of the relationship between federally recognized tribes and the United States government. As "domestic dependant nations," federally recognized tribes exert independent authority over their members. This allows federally recognized tribes to be exempted from the jurisdiction of state governments. Tribal sovereignty encompasses the ability to form a government, determine membership, control natural resources, enforce law and order, and regulate trade and commerce. ${ }^{37}$ Without sovereignty rights, it is impossible for an Indian tribe to function as a distinct governmental entity in a government-to-government relationship with the United States.

Although the federal government acknowledges the sovereignty of Indian tribes, it also acknowledges its own fiduciary responsibility to assure that native tribes have the necessary resources to provide for and protect their distinct cultural heritage. It is this recognition that underlies the breadth of federal services provided to federally recognized tribes.

\section{Federal Services}

Arguably the most important benefit associated with federal recognition is the Indian tribe's eligibility for federal services. These services include "elementary, secondary, and post-secondary education, social services, law enforcement, judicial courts, business loans, land and heirship records, tribal government support, forestry, agriculture and range lands development, water resources, fish, wildlife and parks, roads, housing, adult and juvenile detention facilities, and irrigation and power systems." educational assistance, economic support, and legal representation provide the most needed services to Indian peoples.

\footnotetext{
36) Cherokee Nation v. Georgia, 30 U.S. (5 Pet.) 1, 17 (1831).

37 See PEvar, supra note 10, at 82 (enumerating these as the "most important areas of tribal authority").

38 BUREAU Of INDIAN AfFairs, STRATEgic: Plan 3 (2001) (on file with author).
} 


\section{a. Education}

The United States has a long history of providing educational assistance to Native Americans. Educational services are provided by a number of federal bureaucracies, including the Bureau of Indian Affairs and the Department of Education. ${ }^{39}$ In 1992, $\$ 39.4$ million of federal support was made available exclusively to Indian college students in the form of scholarships and grants." Although these programs were drafted to provide services for "Native Americans" (without defining the term), the development of federal recognition has led many programs to limit their services to those tribes formally recognized by the federal government. For example, university and college admissions officers have required proof of Indian status before considering a student for educational programs or special consideration." If an individual comes from a nonrecognized tribe, she has no means of satisfying such documentation requirements. As a result, these programs are only available to federally recognized Indians.

Educational support for secondary education provides meaningful opportunities for Native Americans who have a formal relationship with the United States. Educational assistance, however, is only one of many types of federal service provided to members of federally recognized tribes. Economic support is another area of federal assistance that is vital to Indian communities.

\section{b. Economic support}

Economic support for recognized Indian tribes is provided in two ways: federal loans and gaming privileges. Federal loans provide Native Americans needed access to funds for community improvement. When federal loans are not enough, gaming privileges help to augment the financial needs of Indian tribes.

One of the more important outcomes of the Indian Reorganization Act was the establishment of revolving credit lines for American

3" See PEVAR, supra note 10, at 268-71 (listing federal administrative bodies that provide Indians with services, and describing the educational programs administered by state and federal governments).

40) Angela Gonzales, The (Re)Articulation of American Indian Identity: Maintaining Boundaries and Regulating Access to Ethnically Tied Resoncres, 22 AM. INDIAN CULTURE \& RES. J. 199, 213-14 (1998).

41 The admissions office of the University of California, Los Angeles, for example, requires that all "American Indian, Alaskan Native, and Native Hawaiian graduate students ... provide documentation of status" when applying as Native Americans. Id. at 214. 
Indians. ${ }^{42}$ Coupled with the Oklahoma Welfare Act, ${ }^{43}$ the federal government established a revolving credit line totaling twelve million dollars by 1936 for recently incorporated tribal communities. ${ }^{44}$

The second, and more controversial, economic benefit available to recognized tribes is a limited exemption from state gaming laws. With the passage of the 1988 Indian Gaming Act, ${ }^{45}$ tribes are permitted to use gaming for economic advancement. ${ }^{4 i}$ The most well-known case of economic growth via gaming privileges is that of the Mashantucket Pequot Tribe of Connecticut. With the success of their casino, Foxwoods, ${ }^{47}$ the Mashantucket Pequot tribe now has the means to acquire extensive amounts of land in the state of Connecticut, illustrating one potential advantage of this particular economic benefit for recognized tribes. The controversy over gaming rights has cast a shadow over federal recognition, though, causing many government and tribal officials to question whether the petitioning tribe is seeking recognition of their Indian heritage, or simply seeking economic gain. $^{48}$

\section{c. Legal protection}

The third significant benefit of federal recognition is the legal protection of the federal government. As a result of the government's trust obligation to Native Americans, the United States has a "duty of

${ }^{42}$ Pub. L. No. 73-383, \$ 10, 48 Stat. 984, 986 (1934) (codified as amended at 25 U.S.C. $\$ 470(2000))$.

Pub. L. No. 74-816, 49 Stat. 1967 (1936) (codified as amended at 25 U.S.C. $\$ \S$ $501-509(2000))$.

${ }^{44}$ FElix S. COHEN, HandboOK Of Federal Indan LaW 246 (1942).

${ }^{45}$ Pub. L. No. 100-497, $\$ 2,102$ Stat. 2467 (codified as amended at 25 U.S.C. $\$ \S$ 2701-2721 (2000)).

${ }^{46}$ See 25 U.S.C. $\$ 2701(5)$ (2000) ("Indian tribes have the exclusive right to regulate gaming activity on Indian lands if the gaming activity is not specifically prohibited by Federal law and is conducted within a State which does not, as a matter of criminal law and public policy, prohibit such gaming activity.").

${ }^{47}$ See JefF Benedict, WITHOUT RESERVATION: THE MAKING OF AMERICA's Most POWERFUl INDIAN TRIBE AND FoxwOOdS, THE WORLd'S LARgest CASINO 226-28 (2000) (discussing the immediate success of the Foxwoods casino and the one million annual salary of the casino's director).

${ }^{4 *}$ See Federal Recognition: Hearing Before the S. Comm. on Indian Affairs, 106th Cong. 55 (2000) (statement of Kevin Gover, Assistant Secretary of Indian Affairs, Department of the Interior) [hereinafter Hearing Before the S. Comm. on Indian Affairs] (voicing his concern with the "financial backing" of some tribes seeking federal recognition and the large amounts of gambling revenue at stake in the process, both of which "obscure... the truth" of tribal recognition and make the administrative process more difficult). 
protection" toward Indians which encompasses legal representation. ${ }^{49}$ Generally, "most of the major court battles over Indian rights to water, land, and wildlife, have been brought by the United States on behalf of ... Indian tribe[s]. ${ }^{50}$ The United States government takes an active role in protecting the rights of Indian groups with whom they have an established government-to-government relationship.

Educational, economic, and legal assistance are the primary resources provided to federally recognized tribes. These services are denied to nonrecognized tribes on the assumption that these tribes are not "legitimately" Indian." This belief has influenced not only the way federal bureaucracies view nonrecognized tribes, but also how nonrecognized tribes perceive themselves.

\section{Prestige and Honor}

The term "federally recognized tribe" has become synonymous with "true" Indian heritage. ${ }^{52}$ As a result, "nonrecognized tribe" has become associated with the "[s] tigma of second class Indian." The widespread belief is that if an individual is not recognized, she "can-

49. See PEVAR, supra note 10, at 26-27 (stating that "[ $\mathrm{t}]$ he federal government's obligation to ... fulfill its treaty commitments is known as its trust responsibility," and noting that this trust responsibility was extended to federal statutes, implied obligations, and loyalty by the federal government).

Id. at 289 .

51 See infra Part III.B.3 (explaining the recognition process's bias in favor of an unrealistic conception of "ideal" tribal identity).

${ }_{52}$ This association may be a result of the legislative narrowing of the term "Indian" in federal statutes. Although these statutes were intended for "Indians" generally, they have been interpreted in recent years to only include federally recognized tribes. Many current statutes define "Indian" by reference to the (somewhat elliptical) tribal definition provided by the 1975 Indian Self-Determination Act: "Indian tribe' means any Indian tribe ... which is recognized as eligible for the special programs and services provided by the United States to Indians because of their status as Indians." 25 U.S.C. $\$ 450 \mathrm{~b}$ (e) (2000); see Indian Financing Act, 25 U.S.C. $\$ 1452$ (b)-(c) (2000) (defining "Indian" and "Tribe"); Indian Health Care Improvement Act, 25 U.S.C. \$ 1603 (c)-(d) (2000) (same); Indian Child Welfare Act, 25 U.S.C. $\$ 1903$ (8) (2000) (defining "Indian tribe"); Indian Alcohol and Substance Abuse Prevention and Treatment Act, 25 U.S.C. $\$ 2403(3)$ (2000) (same); Tribally-Controlled Schools Act, 25 U.S.C. \$ $2511(2)(2000)$ (same); Native American Graves Protection and Repatriation Act, 25 U.S.C. $\$ 3001(7)(2000)$ (same).

5:3 Federal Acknowledgment Process: Hearing Before the Select Comm. on Indian Affairs, 96th Cong. 7 (1980) (statement of LaDonna Harris, President, Americans for Indian Opportunity) 
not be Indian." ${ }^{, 4}$ Nonrecognized tribes frequently pursue recognition for the "prestige and honor in establishing the government-togovernment relationship with the United States." As Charles Blackwell and J. Patrick Mehaffey explain, "For these people, acknowledgment is an affirmation of [their] heritage and official recognition of their tribal ancestry: an expression of their Indian pride."

Federal recognition affords those who possess it jurisdiction over their peoples, access to an extensive list of federal services, and validation of their inherent Indian identity. Nonrecognized tribes lack the authority, the resources, and the status to truly claim their Indian heritage. It was this understanding of the plight of nonrecognized Indian tribes that led Congress in the 1970 s to investigate the historical and contemporary situation of nonrecognized tribes and suggest legal mechanisms by which nonrecognized tribes could become federally recognized.

\section{THE Federal ACKNOWLEDGment Process}

In 1975, Congress established the American Indian Policy Review Commission (AIPRC) to survey the current status of Native Americans within the continental United States. ${ }^{57}$ Task Force Ten of the AIPRC specifically investigated the situation of terminated and nonrecognized tribes. ${ }^{58}$ After two years of intensive investigation, Task Force Ten found that the "results of 'nonrecognition' upon Indian communities and individuals have been devastating." The Task Force recommended that clear procedures be enacted to provide "a candle in the darkness of confusion and neglect which surround terminated and nonfederally recognized American Indian people." It was the Task Force's intention that these procedures would expressly end the

54 Indian Federal Acknowledgment Process: Hearing Before the H.R. Comm. on Interior $\mathfrak{F}^{\circ}$ Insular Affairs, 102d Cong. 156 (1992) (statement of Bud Shepard, Former Bureau of Indian Affairs Employee).

${ }_{55}$ Blackwell \& Mehaffey, supra note 19 , at 56.

56) Id.

57 Paschal, supra note 34, at 212.

58 TASK FORCE TEN: TERMINATED AND NONFEDERALly RECOGNIZED INDIANS, REPORT ON TERMINATED AND NONFEDERALLY RECOGNIZED INDIANS: FINAL REPORT TO THE AMERICAN INDIAN POLICY REVIEW COMMISSION 3 (1976).

Id. at 1695 .

id. at 4. 
practice of categorizing Native American tribes as federally recognized or non recognized."

In response to AIPRC recommendations and congressional approval of the Commission's suggestions, the Department of the Interior (DOI or the Department) sought to establish a uniform procedure for the recognition of previously nonrecognized tribes. ${ }^{6 i 2}$. In 1978 , the DOI, pursuant to its congressional authority, ${ }^{63}$ established an administrative mechanism by which nonrecognized tribes could become eligible for federal services and legal protections. ${ }^{\text {ti4 }}$ Also known as the Federal Acknowledgment Process (FAP), the express purpose of this regulation ${ }^{6.5}$ was to "establish a departmental procedure and policy for acknowledging that certain American Indian groups exist as tribes." The DOI's procedure for becoming federally recognized entails extensive documentation and proof of legitimate Indian status, which in reality creates further difficulties for nonrecognized tribes rather than provide a means for recognition of all Indian tribes.

\section{A. Meeting the Criteria}

To begin the process of federal acknowledgment, Indian petitioners must provide a letter of intent. ${ }^{67}$ Next, the Indian tribe gathers the

(1) See id. at 1698 ("[T] he statutes do not authorize the [federal recognition] distinction. The [Terminated and Nonfederally Recognized Indians Task Force] concludes that 'non-federally recognized' should not be used in any official way and should be rendered harmless.").

${ }^{62}$ See Mark D. Myers, Federal Recognition of Indian Tribes in the United States, 12 STAN. L. \& POL'Y REV. 271, 273 (2001) (noting that the Bureau of Indian Affairs (BIA) “"raced to draft [these] administrative guidelines" in order to preempt congressional action (quoting Peter Beinart, Lost Tribes: Native Americans and Government Anthropologists Feud over Indian Identity, LINGUA FRANCA, May/June 1999, at 33)).

Se. Se 25 U.S.C. $\$ \$ 2,9$ (2000) (granting the Executive branch the "management of all Indian affairs" and the authority to "prescribe such regulations as [the President] ... think[s] fit for carrying into effect the various provisions of any act relating to Indian affairs").

${ }^{\text {ti4 }}$ Procedures for Establishing That an American Indian Group Exists as an Indian Tribe, 25 C.F.R. $\$ 83$ (2002).

It is important to note that the FAP is a regulatory, rather than statutory regime, and that Congress has not developed its own mechanism for Indian acknowledgment.

(ifi 25 C.F.R. $\$ 83.2$ (2002). There are currently 562 federally recognized Indian tribes in the United States. See Indian Entities Recognized and Eligible to Receive Services from the United States Bureau of Indian Affairs, 67 Fed. Reg. 46,328 (July 12, 2002) ("562 tribal entities [are] recognized and eligible for funding and services . . . by virtue of their status as Indian tribes.").

ii See 25 C.F.R. $\$ 83.4$ (a) (2002) ("Any Indian group ... that believes it should be acknowledged as an Indian tribe . . may submit a letter of intent."). 
required documentation to establish its eligibility for federal acknowledgment. DOI regulations require that the putative tribe submit documentation to satisfy all of the following criteria:

(a) The petitioner has been identified as an American Indian entity on a substantially continuous basis since 1900 .

(b) A predominant portion of the petitioning group comprises a distinct community and has existed as a community from historical times until the present.

(c) The petitioner has maintained political influence or authority over its members as an autonomous entity from historical times until the present.

(d) A copy of the group's present governing document .... [T] he petitioner must provide a statement describing in full its membership criteria and current governing procedures.

(e) The petitioner's membership consists of individuals who descend from a historical Indian tribe or from historical Indian tribes which combined and functioned as a single autonomous political entity.

(f) The membership of the petitioning group is composed principally of persons who are not members of any acknowledged North American Indian tribe.

(g) Neither the petitioner nor its members are the subject of congressional legislation that has expressly terminated or forbidden the Federal relationship.

Once the petition is complete, the tribe submits it to the DOI for review. If the petition includes all the required information, the Secretary of the Interior will place the tribe on "active consideration" and issue proposed findings within one year as to whether the Indian tribe should be federally recognized. ${ }^{6 \cdot 9}$ Once a tribe is recognized, it becomes "eligible for the services and benefits ... that are available to other federally recognized tribes" and "shall be entitled to the privileges and immunities available to other federally recognized historic tribes by virtue of their government-to-government relationship with the United States." ${ }^{, 70}$ As written, the federal procedures for acknowl-

(i8 25 C.F.R. $\$ 83.7$ (2002).

6!) 25 C.F.R. $\$ 83.10$ (2002). However, the BIA typically takes much longer to decide petitions. See Hearing Before the S. Comm. on Indian Affairs, supra note 48, at 57 (statement by Richard Velky, Chairman of the Schaghticoke Nation) (arguing that it may take the BIA ten to twelve years to reach a final determination of tribal status); see also Muwekma Tribe v. Babbitt, 133 F. Supp. 2d 30, 40 (D.D.C. 2000) (estimating that it will take the DOI twenty years to review the plaintiff tribe's petition).

${ }^{70} 25$ C.F.R. $\$ 83.12$ (a) (2002). 
edgment appear to provide a reasonable and clear means of determining which Indian tribes should become federally recognized. However, the neutral language of the regulations conceals the harsh realities faced by nonrecognized petitioners.

\section{B. Hardships for Nonrecognized Tribes}

The express purpose of developing a uniform means of recognizing American Indians was to provide a relatively easy and straightforward means for nonrecognized tribes to establish a federal-Indian relationship. In fact, however, the adoption of the FAP has caused further pain and suffering to an already weak and neglected portion of the Indian community. Specifically, nonrecognized tribes face large financial, emotional, and cultural costs when attempting to navigate the FAP.

\section{Time and Money}

While the regulatory procedures for federal recognition may appear straightforward, the actual task of compiling the petition requires considerable amounts of time and money. The creation of the documents alone has been estimated to take between two-and-a-half and five years. ${ }^{71}$ During this time, the tribe must hire an array of experts: anthropologists to validate the existence of a current tribal community, genealogists to trace tribal ancestry, and lawyers to oversee the process. ${ }^{72}$ These professionals are required to substantiate the tribe's fulfillment of the FAP criteria. On average, tribes have paid between $\$ 300,000$ and $\$ 500,000$ for the creation of their petition. ${ }^{73}$ Some petitioners have paid more than a million dollars for their documentation. $^{74}$ Although some private and public organizations help to provide funding, ${ }^{75}$ for the most part, the expenses are borne by the tribes themselves.

${ }^{71}$ Blackwell \& Mehaffey, supra note 19, at 59. In fact, this may be a conservative estimate. Cf. United States v. 43.47 Acres of Land, 45 F. Supp. 2d 187, 194 (D. Conn. 1999) (noting that it took the plaintiff tribe sixteen years to complete its application).

${ }_{72}$ Paschal, supra note 34 , at 216-17.

${ }^{73}$ Federal Recognition of Indian Tribes: Hearing on H.R. 2549, H.R. 4462, and H.R. 4709 Before the Subcomm. on Native Am. Affairs of the House Comm. on Natural Res., 103d Cong. 167 (1994) [hereinafter, Hearing on Federal Regulation of Indian Tribes] (statement of Bud Shepard, former BlA employee and one of the original drafters of the federal regulations).

${ }_{74}^{7} I$.

${ }^{75}$ See, e.g., James v. Dep't of Health \& Human Servs., 824 F.2d 1132, 1134 (D.C. 
The length of time the DOI takes to review a petition can have disastrous effects on the tribe's ability to document and prove its Indian ancestry. During the FAP process, important tribal leaders may die who may have been able to provide necessary first-hand information to federal investigators. Richard Velky, Chief of the Schaghticoke Tribal Nation, has noted that during his tribe's involvement in the FAP, "several elders" have died who "were an important link to the history, community, governance and culture of Schaghticoke for the first half of the 20 th century."

\section{Emotional Costs}

In addition to the consequences of time and money, there are significant emotional costs associated with revealing tribal members' personal stories and the community's history to a federal agency. Many Native Americans, just as most people, desire to keep their private and personal affairs protected from public scrutiny. Unfortunately, the FAP does not grant Native Americans discretion in revealing their most intimate familial relationships and cultural practices. For some tribes, such as the Piro/Manso/Tiwa Tribe, disclosing information about their community life violates their traditions and results in considerable emotional loss when this information is revealed to individuals outside the tribe. ${ }^{78}$ During the FAP process, "unrecognized tribes are ... asked to document very personal, private, sacred, [and] painful" information which could involve "family memories and information about deceased individuals which ... include memories of abuse, abandonment, or other family problems."

When Indian familial relationships are scrutinized by the federal government they are not only compared to notions of "normal" American family relations, but more importantly, are analyzed against notions of the "proper" Indian family life. This latter idealization of

Cir. 1987) (noting that the nonrecognized tribe from the Department of Health and Human Services provided two grants totaling approximately $\$ 175,000$ to a nonrecognized tribe).

${ }^{76}$ See Hearing on Federal Regulation of Indian Tribes, supra note 73, at 231 (reproducing a letter from Margaret Greene, Samish Indian Tribe, to Rep. Bill Richardson, Chairman, House Subcomm. on Native Am. Affairs 1 (Aug. 3, 1994), stating that the tribe paid for most of the expenses incurred in its recognition application process).

${ }^{7}$ Hearing Before the $S$. Comm. on Indian Affairs, supra note 48, at 86 (statement of Richard L. Velky, Chief, Schaghticoke Tribal Nation).

${ }^{78}$ Id. at 59 (statement of Louis Roybal, Governor, Piro/Manso/Tiwa Tribe).

${ }^{79} \quad I d$. at 89 . 
Indian communities has resulted in another layer of problems associated with the FAP for nonrecognized tribes.

\section{The Ideal Tribe}

In addition to creating difficulties of time, money, and emotional costs, the FAP conceptually requires proof of an "ideal tribe," rather than identifying the current, realistic characteristics of Native American life. ${ }^{80}$ One of the leading assumptions of the federal regulations "is that tribal identity is innate: that a tribe develops as an organic entity, taking its shape from internal forces rather than from external forces." This assumption has allowed many tribes that predate European contact to remain nonrecognized. ${ }^{82}$ The regulations do not reflect a cultural and historical understanding of the current nature of American Indian tribes. As such, the criteria function not to increase the number of Indians benefiting from the federal-Indian relationship, but rather to "deny... Indian groups official recognition ... thereby limit[ing] their access to federal services."

The AIPRC's intent in researching and recommending formal procedures for Indian recognition was to alleviate the hardships suffered by nonrecognized tribes. The FAP was meant to provide such a streamlined approach. In reality, the FAP has created new problems for non recognized tribes by requiring them to pay exorbitant amounts of money over long periods of time and to reveal painful community histories, which likely cannot live up the image of the "proper" Indian tribe. Recognizing the injustices associated with the FAP, many Indian tribes, their advocates, and their legal counsel turned to the federal courts for assistance. Because the FAP was developed only in 1979 , the federal judiciary was faced in 1993 with a matter of first impression: to what extent would the court honor and enforce promises made to nonrecognized Indian tribes against the power and authority delegated to the DOI?

so See Dan Gunter, The Technology of Tribalism: The Lemhi Indians, Federal Recognition, and the Creation of Tribal Identity, 35 IDAHO L. REV. 85, 89 (1998) ("In short, the [federal] recognition criteria assume an 'ideal tribe.' ... A putative tribe that lacks [these ideal characteristics] may well fail to earn federal recognition.").

1 Id. at 88 .

${ }^{82}$ See Margo S. Brownell, Who Is an Indian? Searching for an Anstuer to the Question at the Core of Federal Indian Law, 34 U. MICH. J.L. REFORM 275, 302 (2001) (noting that 25 C.F.R. $\$ 83$ continues to leave many tribes that existed prior to the sixteenth century unrecognized by the federal government).

${ }^{83}$ Gunter, supra note 80 , at 98. 


\section{LEGAL ACTIONS FOR NONRECOGNIZED TRIBES}

Nonrecognized tribes and their counsel went to court hopeful that judicial action would provide relief from the historical and bureaucratic hardships they have faced for two hundred years. Optimistic that judicial inquiry would provide the necessary "outside force" to compel change within the DOI, a number of nonrecognized tribes filed suit against the Department.

\section{A. Judicial Deference to the Department of the Interior}

For the first twenty years of litigation on the FAP, nonrecognized tribes challenged the DOI's power to recognize Indian tribes. Either by directly attacking the legal grounds upon which the DOI promulgated the federal regulations, or seeking direct federal recognition from the judiciary, nonrecognized tribes asked the courts to focus on matters of substantive, rather than procedural fairness.

\section{Direct Attacks on DOI Authority and Decision Making}

Two tribes directly challenged the DOI's authority to deny federal recognition of an Indian tribe, the Miami and United Houma Nations. Both tribes asked the courts to consider the particular merits of their claims; in both cases, the federal judiciary avoided the substantive claims of these nonrecognized tribes through complete deference to the DOI's regulatory decision-making authority. By turning a blind eye to the contemporary plight of nonrecognized tribes, the courts assured that old promises would not be kept to these historical tribes.

\section{a. The Miami Nation}

The aboriginal lands of the Miami Nation are located in Peru, Indiana, and "[b]etween 1795 and 1840, the Miamis entered into a number of treaties with the United States, ceding millions of acres of land." ${ }^{84}$ The final treaty between the tribe and the United States government relinquished "'all of [the Tribe's] remaining lands in Indiana," provided that within five years the Miami Nation remove from Indiana to an area in east-central Kansas. ${ }^{85}$ Like many nonrecognized tribes, however, only half of the tribe left their historical tribal land, in

${ }^{84}$ Miami Nation of Indians of Indiana, Inc. v. Lujan ("Miami Nation I"), 832 F. Supp. 253, 253 (N.D. Ind. 1993).

Id. (quoting the Treaty of November 28, 1840, 7 Stat. 582). 
this case moving to the Kansas territory. ${ }^{8 i}$ The Miami Indians who remained in Indiana were given individual land grants on the Meshingomesia Reserve. ${ }^{87}$ As "Indian Country," ${ }^{, 88}$ the Meshingomesia Reserve was exempt from Indiana state tax laws." Nevertheless, in the 1880 s, Indiana levied property taxes against individual Miami residents. ${ }^{9 \prime \prime}$ In 1885, the Miami tribe filed a lawsuit against the State and the court found individual tribe members exempt from personal property taxes. ${ }^{91}$ When the Miami Nation approached the DOI to recover their paid taxes, the Assistant Attorney General determined that the Miami Nation was no longer a tribal organization and was not protected by the federal trust relationship. ${ }^{.2}$ Since that decision the DOI has refused to acknowledge the Miami Nation as an Indian tribe leaving them vulnerable to the historical and contemporary costs associated with nonrecognition.

In their first suit, the Miami Nation argued that the decision to withdraw federal recognition was ultra vires because only Congress has the power to terminate federal-tribal relations.." Rather than examine the substantive argument advanced by the Miami Nation, the Indiana federal court determined that the suit was barred by the statute of limitations. ${ }^{.91}$ By focusing on the statute of the limitations, the court was able to avoid an inquiry into the DOI's failure to abide by its trust obligations to the Miami Nation.

The Miami Nation returned to federal court two years later challenging both the authority of the DOI to promulgate the regulations and the validity of the regulations themselves. ${ }^{95}$ The Miami Nation ar-

Bi) at 254 .

${ }^{87}$ Id.

"Indian Country" refers to "all the land under the supervision of the United States government that has been set aside primarily for the use of Indians." PEVAR, supra note 10, at 16. Generally speaking "state jurisdiction does not extend to Indian Country," and "most crimes by Indians within Indian Country are governed by tribal or federal and not state law." Id. at 16.

Miami Nation I, 832 F. Supp. at 254 (citing Wau-Pe-Man-Qua v. Aldrich, 28 F. 489, 493 (C.C.D. Ind. 1886)).

(9i) Id.

Wau-Pe-Man-Qua, 28 F, at 494.

!12 Miami Nation I, 832 F. Supp. at 255.

Id.

Id. at 256-57; see 28 U.S.C. $\$ 2501$ (2000) ("Every claim of which the United States has jurisdiction shall be barred unless the petition therein is filed within six years after such claim first accrues.").

"Miami Nation of Indians of Indiana, Inc. v. Babbitt ("Miami Nation II"), 887 F. Supp. 1158, 1161 (N.D. Ind. 1995). 
gued that the DOI exceeded its authority by issuing regulations that imposed stricter requirements on tribes petitioning after $1978 .^{96}$ Also, the Miami Nation contended that the regulations were invalid because they "fail[ed] to define key terms" and the appropriate "burden of proof," and "provide[d] no mechanism for independent review or administrative appeal.,"17

The court began its analysis of the Miami Nation's claims by determining the appropriate standard of review under the Cheoron doctrine. $^{18}$ Citing previous litigation involving the federal recognition question, ${ }^{\prime \prime \prime}$ the court found the regulations to be legislative, ${ }^{100}$ rather than interpretative, ${ }^{101}$ triggering Cheoron deference. ${ }^{102}$ Though the court agreed that the term "Indian tribe" was not affirmatively defined by Congress, ${ }^{103}$ following the Cheuron doctrine, it determined that when "the grant of authority [is] implicit rather than explicit, the court 'may not substitute its own construction of a statutory provision for a reasonable interpretation made by the administrator of an agency." 104 The court was equally unsympathetic to the Miamis' claims against the regulations for federal recognition. The court found that the regulations were not arbitrary and capricious "simply because the Miamis contend that a few terms are vague or because the burden of proof is unclear." ${ }^{105}$ In addition, Congress had not in-

Id. at 1162 .

97 Id.

Under the Cheuron doctrine, when a court reviews an administrative agency's construction of a statute, it must inquire "whether Congress has directly spoken to the precise question at issue." Chevron U.S.A., Inc. v. Natural Res. Def. Council, Inc., 467 U.S. 837,842 (1984). If congressional intent is clear, the court must give effect to the expressed desire of Congress. If the legislative intent is ambiguous, the court must determine "whether the agency's answer is based on a permissible construction of the statute." Id. at 843 .

${ }^{99}$ See James v. United States Dept. of Health \& Human Servs., 824 F.2d 1132, 1137 (D.C. Cir. 1987) (finding that the Secretary of Health and Human Services's authority to promulgate Procedures for Establishing That an American Indian Group Exists as an Indian Tribe, 25 C.F.R. $\$ 83.2$, is consistent with her authority under 25 U.S.C. $\$ \S 2$, 9).

${ }^{100}$ Legislative regulations are legally binding and must conform to the specific authority of the administrative agencies' enabling act. WILLIAM F. FUNK \& RICHARD H. SEAMON, AdMINISTRATIVE LAW: EXAMPLES \& EXPLANATIONS 137 (2001).

${ }^{101}$ Interpretative rules interpret existing law and do not carry independent legal effect. Id. at 149

${ }^{102}$ Miami Nation II, 887 F. Supp. at 1165.

${ }^{103}$ Id. at 1165-66.

104 Id. at 1167 (quoting Cherron, 247 U.S. at 844).

${ }^{105}$ Id. at 1173 . Note that courts have found the lack of a formal hearing violative of a tribe's right to procedural due process if the tribe can demonstrate that it received 
tended "to require a [formal] hearing and opportunity for crossexamination" given that the federal acknowledgment procedures "were promulgated under the informal rulemaking procedure" of the Administrative Procedures Act. ${ }^{107}$ By focusing on Cheoron deference, the court was able to affirm the DOI's process for recognition without inquiring into the actual fairness of the FAP itself. The Chevron doctrine, therefore, allowed the court to avoid the real question of whether the federal government had honored its trust responsibilities to the Miami Nation.

In its final attempt to challenge the DOI's judgment that it was not a federally recognized tribe, the Miami Nation argued: (1) the DOI had acted arbitrarily and capriciously in finding that the Miami Nation did not meet the qualifications of a historic tribe; ${ }^{101}$ (2) the Miami Nation was entitled to a reevaluation under the current revised regulations; and (3) recent amendments to the Indian Reorganization Act (IRA) restored the Miami Nation's federal status.

After reviewing the DOI's findings, the court found that unless the decision was premised on factors not intended by Congress or was implausible in light of the evidence, it was not arbitrary and capricious. ${ }^{110}$ The court also discounted assertions that the DOI had acted arbitrarily and capriciously in its dealings with the Miami Nation."' Finally, the court determined that the Miamis were not entitled to a rehearing on their tribal status due to the 1994 amendments of the IRA or the federal regulations, concluding that the amendments were intended to clarify the existing law and were not retroactive. ${ }^{112}$ As in the Miami

federal benefits prior to the enactment of the federal regulations and then were subsequently denied the continuation of those benefits. See Greene v. Lujan, No. C89645Z, 1992 WL 533059, at*1 (W.D. Wash. Feb. 25, 1992) (holding that the Samish Indians derived a protected property interest in their status as a tribe on the basis of past federal benefits received by its members), affd sub nom. Greene v. Babbitt, 64 F.3d 1266, 1275 (9th Cir. 1995). The court in Miami Nation II distinguished Greene on the grounds that the Miami tribe had not been receiving federal benefits prior to their denial of federal recognition. Miami Nation II, 887 F. Supp. at 1175 n.4.

${ }_{106}$ Miami Nation II, 887 F. Supp. at 1173 .

${ }^{107}$ See 5 U.S.C. $\$ 553$ (2000) (describing federal rulemaking procedures under the Administrative Procedures Act).

${ }^{108} 25$ C.F.R. $\$ 83.7$ (2002) (providing the mandatory criteria for federal acknowledgement of historic tribes).

10!' Miami Nation of Indians of Indiana v. Babbitt, ("Miami Nation III") 112 F. Supp. 2d 742, 744 (N.D. Ind. 2000).

\footnotetext{
ld. at 751 .

11 Id. at $751-58$.

${ }^{112}$ Id. at 760 .
} 
Nation's previous litigation efforts, the federal court ignored the substantive issues presented in favor of judicial deference to the DOI.

The Miami Nation attempted a variety of legal attacks on the DOI's administration of the FAP. While each claim was grounded in a judicially cognizable action, the Miami Nation was appealing to the court's sense of fairness. In other words, the Miami Nation asked the judiciary to honor the federal government's trust obligations toward all Native Americans and restore the Miami Nation to its formally recognized status. Instead, the judiciary hid behind procedural barriers to review and judicial deference to the DOI. In the end, the Miami Nation was forced to "accept the procedures and obligations of the legal system" that "deter courts from deciding cases on the merits." "11:

\section{b. The United Houma Nation}

The United Houma Nation similarly attempted to challenge the practices and procedures of the DOI in federal court. The United Houma Nation (UHN) originally inhabited the Terrebonne and Lafourche Parishes southwest of New Orleans, Louisiana. ${ }^{114}$ Like many nonrecognized tribes, the UHN intermarried with French Creoles and African Americans in order to escape governmental involvement. ${ }^{15}$ Today, the UHN is one of the largest state-recognized tribes of Louisiana. $^{1 / 6}$ However, despite its efforts to challenge the DOI's effectiveness, the UHN remains federally unrecognized.

The UHN filed a Letter of Intent with the DOI in 1979 when federal petitioning began. ${ }^{117}$ Preliminarily denied federal acknowledgment on December 22, 1994, the UHN petitioned the DOI on May 13, 1995 for a rulemaking on the theory that the criteria upon which their petition was originally denied had become invalid under the 1994 amendments. The UHN further asked that the DOI revise the federal regulations accordingly. ${ }^{1 / 8}$ The DOI declined to engage in informal rulemaking leading the UHN to seek a judicial declaration that the

11.9 Gerald N. ROSEnberg, Tle Hollow hope: Can Courts Bring about Social CHange? 12 (1991) (quoting Council for Public InTERest Law, Balancing, THE SCAles Of JUSTICE: FinANCING PUblic INTEREST LAW IN AMERICA 855 (1976)).

${ }^{114}$ Jordan S. Dill, Houmn History, at http://dickshovel.com/hou.html (last visited Apr. 17, 2003).

$115, I d$.

11i; Id.

${ }^{117}$ United Houma Nation v. Babbitt, No. Civ.A. 96-2095, 1997 Wl. 403425, at *1 (D.D.C. July 8, 1997).

ild. 
current criteria, specifically the historic tribe requirement, be revised. ${ }^{1 ! 9}$ The district court reasoned that their review of an administrative agency's refusal to initiate rulemaking procedures was "very narrow.", "20 Agency decisions would only be overturned "in the rarest and most compelling circumstances."'21 Noting that Congress had not directly addressed the issue of federal recognition or the regulations developed by the Department, the court found "the agency's acknowledgment regulations [to be] entitled to deference under Chevron." ${ }^{\prime 22}$ By limiting the judiciary's ability to review the decisions of the DOI, the court turned a blind eye to the harsh reality facing nonrecognized tribes in the FAP.

\section{c. A standard of judicial deference to the DOI}

The Miami Nation and the UHN attempted a variety of legal claims aimed at judicial inquiry in to the authority and practice of the DOI. In both instances, the judiciary did not even attempt to inquire into the factual and historical circumstances surrounding the Miami Nation and UHNs current nonrecognized status. Regardless of the substantive claim, the judiciary gave complete and total deference to the decisions and actions of the DOI.

Given these precedents, it appears fruitless for nonrecognized tribes to become involved in litigation. In order to avoid judicial deference to the DOI, a nonrecognized tribe must prove that the DOI has exceeded its authority by enacting rules inconsistent with its congressional delegation. ${ }^{123}$ At the same time, the DOI's congressional authority is so broad that it is unlikely that a tribe would be able to demonstrate such overreaching, effectively closing the door to federal recognition litigation. ${ }^{124}$

119 Id. at $* 2$. 1984)).

120) It. at *6 (quoting Ark. Power \& Light Co. v. ICC, 725 F.2d 716, 723 (D.C. Cir.

${ }^{121}$ Id. (quoting W. Fuels-IIl., Inc. v. ICC, 878 F.2d 1025, 1027 (7th Cir. 1989)).

122 Id. at $* 8$.

123 Cf. supra text accompanying notes 103-12 (reviewing the Miami Nation's unsuccessful efforts to convince a federal district court that the DOI acted either unreasonably or arbitrarily and capriciously in deciding that the Miamis were no longer a tribal organization).

124. See supra note 63 (describing the breadth of the language with which Congress delegated to the DOI the authority to review federal recognition applications). 


\section{Exhaustion and Primary Jurisdiction}

Beyond extending extreme judicial deference to the DOI, courts confronted with tribes seeking a judicial declaration of recognition "have with high predictability invoked either exhaustion or primary jurisdiction." The exhaustion doctrine "prevent[s] the courts... from entangling themselves in abstract disagreements over administrative policies," and also "protect[s] the agencies from judicial interference until an administrative decision has been formalized." sues of primary jurisdiction arise "where a claim is originally cognizable in the courts, and comes into play whenever enforcement of the claim requires the resolution of issues which, under a regulatory scheme, have been placed within the special competence of an administrative body."127

In the federal acknowledgement context, both exhaustion and primary jurisdiction prevent the judiciary from considering the substantive issues brought by nonrecognized tribes prior to the time that the DOI has come to a final resolution. These procedural barriers thwarted the efforts of five tribes seeking federal recognition: the James Group, the Golden Hills Paugussett Tribe, the Schagticoke Tribe, the United Tribe of Shawnee Indian, and the Burt Lake Band of Ottawa and Chippewa Indians. The following case examples leave little hope that the courts are willing to recognize the government's trust obligations to Indians over the delegated power and authority of the DOI.

\section{a. The James Group}

The seminal case involving the exhaustion doctrine in the context of federal acknowledgment is James $v$. United States Department of Health $\mathcal{E}$ Human Services. ${ }^{128}$ In James, a nonrecognized tribe, referred to as the James Group, claimed that another faction of the same original tribe, the Widdis Group, had fraudulently received funding from the

${ }^{125}$ John W. Ragsdale, Jr., The United Tribe of Shatomee Indians: The Battle for Recognition, 69 UMKC L. REV. 31 1, 328 (2000).

${ }^{126} 2$ Federal. PROCEdURE, LAWYERS' EDITION $\$ 2: 298$ (1994); see also Rebecca L. Donnellan, Student Work, The Exhaustion Doctrine Should Not Be a Doctrine with Exceptions, 103 W. VA. L. REV. 361, 366-69 (2001) (discussing the general rationale behind exhaustion and the specific administrative and judicial interests that are served).

${ }^{127}$ United States v. W. Pac. R.R., 352 U.S. 59, 64 (1956); see id. (“"[I]n such a case the judicial process is suspended pending referral of such issues to the administrative body for its views.").

${ }_{128} 824$ F.2d 1132,1133 (D.C. Cir. 1987). 
Department of Health and Human Services. ${ }^{12 !}$ The Widdis Group incorporated in 1972 as the Wampanoag Tribal Council (Tribal Council) for the purpose of seeking federal recognition. ${ }^{130}$ The Tribal Council procured approximately $\$ 175,000$ in grants from the Department of Health and Human Services to assist it in the process. ${ }^{131}$ The Tribal Council was ultimately successful in its pursuit of federal recognition, achieving that status in $1987 . .^{132}$ Unlike the Tribal Council, the James Group sought a judicial declaration that it was already federally recognized. ${ }^{133}$ The D.C. Circuit concluded that the decision of whether the James Group's evidence was sufficient for recognition "should be made in the first instance by the Department of the Interior." Finding that judicial determinations of Indian status would frustrate the congressional delegation of this authority to the DOI, ${ }^{135}$ the court declined to address the James Group's claim that it was a federally recognized tribe. Instead, the court remanded the decision to the DOI. ${ }^{136}$ Once again, rather than consider the substantive claims of a nonrecognized tribe, the court deferred to the DOI.

\section{b. The Golden Hill Paugussett Tribe}

Six years later, the Golden Hill Paugussett Tribe of Indians attempted to recover native lands illegally purchased under the Nonintercourse Act. ${ }^{1: 37}$ These native lands covered thousands of acres in Fairfield and New Haven counties in Connecticut. ${ }^{138}$ Although the Tribe was recognized by the State of Connecticut ${ }^{139}$ the Golden Hill were still awaiting final determination by the DOI. As in James Group, rather than inquiring into the factual nature of the Golden Hill's

129) Id. at 1135 .

${ }^{1510}$ Id. at 1134 .

${ }^{131}$ Id.

132 Id. at 1136.

13.3 Id. at $1136-37$.

134 Id. at 1137.

${ }^{135}$ See id. (observing that the purpose of the regulatory scheme "would be frustrated if the Judicial Branch made initial determinations of whether groups have been recognized previously or whether conditions for recognition currently exist").

I.3ii at $1138-39$.

${ }^{137}$ Golden Hill Paugussett Tribe of Indians v. Weicker, 839 F. Supp. 130, 132 (D. Conn. 1993).

${ }^{198}$ Golden Hill Land Claims, Golden Hill Paugussett Nation, at http://www. goldenhill-landclaims.itgo.com/golden_hill_land_claims.htm (last visited Apr. 17, 2003).

${ }^{139}$ Gall. K. ShefField, The ARbItrary Indian: THE Indian ARTS ANd Crafts ACT OF 1990, at 65 (1997). 
claim, the district court held that "a litigant must exhaust all administrative remedies before seeking judicial relief." ${ }^{140}$ The court expressed concern that allowing judicial review of the tribe's nonintercourse claim under the Indian Nonintercourse $\mathrm{Act}^{141}$ would "encourage avoid[ance] of the DOI's processes, impede uniformity, and multiply proceedings." ${ }^{142}$ Citing judicial and administrative convenience rather than concerns of fairness or justice, the court dismissed the Tribe's nonintercourse claim until such time as the Tribe became federally recognized.

\section{c. The Schagticoke Tribal Nation}

The Schagticoke Tribal Nation, another Connecticut tribe, brought an action in federal court seeking to intervene in the United States government's attempt to acquire 43.47 acres of tribal land for the Appalachian Trail. ${ }^{143}$ This land covered the Tribe's mountainous reservation in Kent, Connecticut. ${ }^{144}$ The Tribe filed its petition for acknowledgment in 1994 while awaiting a decision from the DOI. ${ }^{145}$ The court found that the doctrine of primary jurisdiction required deference to the DOI and refused to consider the Tribe's substantive claims. ${ }^{14 i}$ The court argued that deferring the decision making to the DOI would promote uniformity in the field of federal recognition and would prevent judicial interference with the DOI's procedural framework. $^{147}$ The court reasoned that without such judicial deference, Indian petitioners would be "encouraged to flood the courts," thereby breeding further uncertainty into the area of federal recognition. Once again, the federal court chose the issue of DOI convenience over the substantive claims raised by the nonrecognized tribe and completely ignored the factual situation facing the Schagticoke Tribal

140 Golden Hill Paugussett Tribe, 839 F. Supp. at 1.34.

141 25 U.S.C. $\$ 177$ (2000).

${ }^{142}$ Golden Hill Paugussett Tribe, 839 F. Supp. at 134.

${ }^{143}$ United States v. 43.47 Acres of Land, 45 F. Supp. 2d 187, 189-90 (D. Conn. 1999).

See Tribal History, Schagticoke Tribal Nation, at http://www.schaghticoke. com/summary.htm (last visited Apr. 17, 2003) (describing the Schagticoke tribal base in Kent, Connecticut).

${ }^{145}$ See 43.47 Acres of Land, 45 F. Supp. 2d at 190 (describing the history of the Tribe's filing). The Tribe was eleventh on the list in 1997. Id.

${ }^{14 t}$ See id. at 194 ("[T] he balance of all the factors clearly indicates that deference to [the BIA Branch of Acknowledgement and Research] is warranted.").

${ }_{147}$ Id. at 192 .

148 ld. 
Nation. While the tribe waited for the DOI to make a decision as to its recognized status, its land was threatened by judicial action against which the tribe was wholly unable to protect itself. By turning a blind eye to the plight of the Schagticoke Tribal Nation, the federal court ensured that the Tribe would lose the last pieces of its aboriginal territory.

\section{d. The United Tribe of Shawnee Indians}

In another suit challenging a federal taking of Indian land, the United Tribe of Shawnee Indians (UTSI) brought an action in federal court seeking a declaration that it was a federally recognized tribe entitled to the land at issue. . $^{4 ! \prime}$ Although the UTSI had signed five different treaties with the United States, ${ }^{150}$ the district court declined to consider the merits of its claim and held that the suit was not ripe for review because the DOI had not made a final determination as to the UTSI's status. ${ }^{151}$ Specifically, the court noted that "exhaustion is required when ... a plaintiff attempts to bypass the regulatory framework for establishing that an Indian group exists as an Indian tribe." As in the Golden Hill Paugussett Tribe and 43.47 Acres cases, the federal court refused to consider the basis of the UTSI's claim, choosing instead to defer to the authority of the DOI. ${ }^{153}$ The court's judicial deference prevailed against the issue of honoring the promises made to the UTSI in its five treaties with the United States.

\section{e. The Burt Lake Band of Ottawa and Chippewa Indians}

Most recently, the Burt Lake Band of Ottawa and Chippewa Indians (BLB) filed suit seeking an injunction that would direct the DOI to place the BLB on the list of federally recognized tribes. ${ }^{1.54}$ The

\footnotetext{
149 United Tribe of Shawnee Indians v. United States, 253 F.3d 543, 545-46 (10th Cir. 2001).

${ }^{150}$ Treaty with the Shawnees, May 10, 1854, 10 Stat. 1053; Treaty with the Shawnees, Aug. 8, 1831, 7 Stat. 355; Treaty with the Shawnees, Nov. 7, 1825, 7 Stat. 284; Treaty with the Wyandot, Seneca, Delaware, Shawanese, Potawtomee, Ottawa, and Chippeway, Sept. 19, 1817, 7 Stat. 160; Treaty with the Shawnees, Jan. 31, 1786, 7 Stat. 26; see also Welcome, United Tribe of Shawnee Indians, at http://home.kc.rr $. \mathrm{com} /$ utosi/sindexl.hum (last visited Apr. 17, 2003) (summarizing the treaty relationships between the UTSI and the United States).

${ }_{151}$ Uniled Tribe of Shawnee Indians, 253 F.3d at 545-46.

152 Id. at. 550 .

iss Id. at 551 .

${ }^{154}$ Burt Lake Band of Ottawa \& Chippewa Indians v. Norton, 217 F. Supp. 2d 76, 77 (D.D.C. 2002) (mem.).
} 
BLB's aboriginal lands consist of a "series of interconnecting rivers and lakes" around the shores of Lake Huron. ${ }^{155}$ In 1900, the BLB's members were forced to leave their homeland when a white "landowner" went around the town dousing Indian homes with kerosene. ${ }^{15 i}$ The BLB members argued that they were not required to undergo the DOI's procedures because they were already federally recognized in a number of treaties in the $1800 \mathrm{~s}^{157}$ Citing the previous decisions of James and Shawnee, the D.C. district court granted the DOI's motion to dismiss because the BLB had failed to exhaust administrative remedies. ${ }^{158}$ The court further noted that "direct suit in federal court seeking federal recognition ... is not appropriate relief." ${ }^{\text {"159 }}$ Once again, judicial deference to the authority of the DOI prevented the court from considering the historical and substantive nature of the BLB's claim.

The doctrines of exhaustion, primary jurisdiction, and judicial deference have prevented the judiciary from hearing the substantive cries of nonrecognized tribes. By placing judicial convenience above issues of substantive fairness, the federal judiciary has left nonrecognized tribes at the mercy of the DOI. By turning a blind eye to the struggles of nonrecognized tribes both historically and in the specific process of the FAP, the courts have subjected nonrecognized tribes to a system that requires tremendous amounts of time and money at high emotional costs. By closing the door to judicial review, the federal courts have declared that old promises will not be kept.

\section{B. Judicial Promise for Nonrecognized Tribes}

Thankfully, a couple of recent judicial decisions indicate that judicial avenues remain open to tribes seeking federal recognition who have hit the DOI roadblock. A number of recent cases brought by nonrecognized tribes against the DOI have shed light on the possi-

155 Colonial Point Memorial Foresi and Chaboigan Nature Preserve, Little Traverse Conservancy, at http://www.landtrust.org/NaturePreserves/ColonialPtCulturalHistory. htm (last visited Apr. 17, 2003).

150 Id.

${ }^{15.7}$ See Burt Lake Band, 217 F. Supp. 2d at 78 (“[BLB] asserts that it need not undergo BIA's recognition process because: 1) it was already recognized as a sovereign Indian tribe by the United States in both the Treaty of Washington in 1846 and the Treaty of Detroit in 1855; and 2) BIA has unreasonably delayed processing plaintiffs application.")

${ }^{158}$ See id. at 79 ("[F]ederal recognition does not allow an entity to completely bypass the BIA's recognition process.").

I.5. Id. 
bility of judicial intervention in the federal acknowledgement process, bringing new hope to nonrecognized tribes and their advocates. As was discussed in Part I.A, the DOI is required to decide the status of an Indian tribe's petition within one year of its eligibility for active consideration. ${ }^{160}$ Unfortunately, the DOI rarely makes a decision within a year, causing delay in the tribes' other legal actions and/or continued denial of federal benefits. In 2000 and 2001, the Muwekma Tribe and the Mashpee Wampanoag Tribal Council brought successful mandamus claims against the DOI requesting that the DOI complete its review of their petitions in accordance with its regulations. ${ }^{161}$ Unlike the previous cases by nonrecognized litigants, the court focused on the emotional, legal, and economic costs associated with the delay of federal recognition rather than deferring to the DOI's decision-making authority. As a result, the courts now appear to have turned the corner of assuring that old promises will be kept to nonrecognized tribes.

\section{The Muwekma Tribe}

The Muwekma Tribe of the San Francisco Bay area entered the federal acknowledgment process in 1989. ${ }^{1 \text { ti2 }}$ After filing its petition in 1995 and supplying the DOI with further documentation upon request, the Muwekma qualified for active consideration in March 1998. ${ }^{163}$ The Tribe brought a legal action in the D.C. district court, asking the court to issue a writ of mandamus compelling the DOI to complete its review of the tribe's petition within twelve months. ${ }^{164}$ Looking to the Administrative Procedure Act, the court found that agencies are required "within a reasonable time" to "proceed to conclude a matter presented to it." 165 If an agency does not proceed within a reasonable time, the APA "confers upon the courts authority to "compel agency action unlawfully withheld or unreasonably de-

\footnotetext{
${ }^{(1 i x)}$ For a discussion of the actual time taken by the DOI to decide petitions, see supra note 69 and accompanying text.

1ii Other Indian tribes have successfully avoided the confines of the exhaustion doctrine by claiming that the DOI unreasonably delayed its responsibilities to the tribes. See, e.g., Cobell v. Norton, 240 F.3d 1081, 1108 (D.C. Cir. 2001) (finding that the DOI's mismanagement of Indian trust accounts constituted unreasonable delay warranting equitable remedy by the court).

${ }^{1 \text { ti2 }}$ Muwekma Tribe v. Babbitt ("Mutwekma I"), 133 F. Supp. 2d 30, 32 (D.D.C. 2000)

lis $I d$. at 33 .

Itid Id. at 31 .

${ }^{1155} 5$ U.S.C. $\$ 555$ (b) (2000).
} 
layed." "1iij Claims of unreasonable delay are traditional exceptions to the exhaustion doctrine, ${ }^{167}$ allowing courts to analyze whether the matter requires judicial action.

In assessing claims of unreasonable delay, the district court turned to the D.C. Circuit's opinion in Telecommunications Research $\mathcal{F}^{2}$ Action Center v. FCC (TRAC). ${ }^{\text {lis }}$ The court in TRAC developed useful guidelines for determining when an administrative "agency's delay is so egregious as to warrant [a writ of] mandamus." Th9 "TRAC directs the trial court to consider whether, among other factors, the agency has followed a rule of reason and its enabling statute's timetable for decision making. In assessing agency action, the court should apply stricter judicial scrutiny in matters of human health and welfare, ensure that agency action does not interfere with matters of higher or competing authority, and pay careful attention to the type of interest prejudiced by delay. ${ }^{170}$ If the agency delay is chronic, it results in "'a denial of justice," "171 justifying the federal court's use of its equitable authority. ${ }^{172}$ Applying the TRAC guidelines, the district court found the DOI's two-year delay in processing the Muwekma's petition unreasonable and ordered the Department to submit a proposed schedule for resolving the issue. ${ }^{173}$

In 2000, the district court denied the DOI's motion to dismiss the Muwekma litigation. ${ }^{174}$ When the DOI returned to court one year later with only a proposed timeframe for placing the Muwekma Tribe on the active consideration list, the court found the proposed remedy unacceptable..$^{175}$ The district court stated that its earlier ruling was in-

16t) Muwekma I, 133 F. Supp. 2d at 33 (quoting the Administrative Procedure Act, 5 U.S.C. $\$ 706(1)(2000))$.

167 Id. at 34 .

${ }^{168} 750$ F.2d 70, 80 (D.C. Cir. 1984).

169. Id. at 79 .

170 Id. at 80 .

17 MCI Telecomms. Corp. v. FCC, 627 F.2d 322, 344 (D.C. Cir. 1980) (quoting Nader v. FCC, 520 F.2d 182, 206 (D.C. Cir. 1975)).

172 See Cobell v. Norton, 240 F.3d 1081, 1108 (D.C. Cir. 2001) (finding that the district court "acted well within its broad equitable powers in ordering specific relief" against the Secretaries of the Interior and Treasury in litigation involving Individual Indian Money trust accounts, and concluding that " [i]f a right of action exists to enforce a federal right and Congress is silent on the question of remedies, a federal court may order any appropriate relief" (quoting Franklin v. Gwinnett County Pub. Schs., 503 U.S. 60, 69 (1992)).

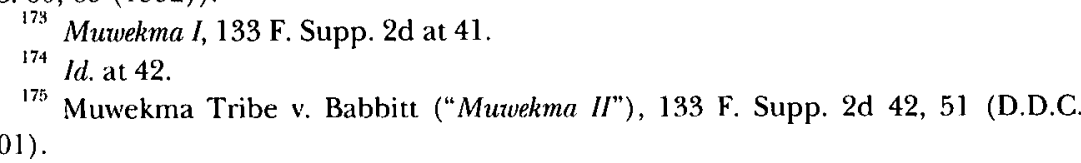


tended to "rectify the past delay," and not to allow the DOI "to proceed on an already delayed course of action." the DOI make a final determination on the Muwekma Tribe's petition by March 11, 2002. ${ }^{177}$ Although the DOI struggled to comply with the court's ruling, the court flatly refused to grant the DOI's subsequent request to vacate the deadline. ${ }^{178}$

\section{The Mashpee Wampanoag Tribal Council}

The court also recognized the material consequences of the DOI's tribal recognition procedures in the case of the Mashpee Wampanoag Tribal Council (MWTC). A year after the conclusion of the Muzekma case, the MWTC filed a similar claim in the same court, asserting unreasonable delay by the DOI in processing its petition. ${ }^{179}$ At the time it filed suit, the MWTC was third on the list of petitions ready for consideration; however, it had languished there for more than five years. ${ }^{180}$ Applying the TRAC factors used in Muwekma, the court concluded that the DOI had unreasonably delayed the MWTC's petition and required the Department to issue a final decision within twelve months of the court's December 2001 ruling. ${ }^{|8|}$

The court also intended that its decision would significantly affect the Department's FAP. Recognizing the hardships faced by nonrecognized tribes, the court noted that

[a] more hopeful scenario, however, is that BIA will be moved by these two orders, or by an accumulation of them, to reallocate its resources, or streamline its decisionmaking process, or contract out some of the work that needs to be done on a petition for acknowledgment, or seek additional revenues from Congress for that task, or do any of the many other things that agencies can do when they must.

Rather than defer to the DOI's timetable, the court examined the reality faced by nonrecognized tribes in the FAP. Instead of turning a blind eye to their plight, the court specifically noted the human costs

$17 i \mathrm{ld}$

177 Id.

${ }^{178}$ Muwekma Tribe v. Norton ("Murvekma III"), 206 F. Supp. 2d 1, 4 (D.D.C. 2002).

179 Mashpee Wampanoag Tribal Council, Inc. v. Norton, 180 F. Supp. 2d 130, 132

(D.D.C. 2001).

Id. at 133

181 Id. at 137 .

${ }^{182}$ Id. at 136 
associated with the DOI's delay. ${ }^{18: 3}$ While the judiciary still recognized and honored the DOI's authority to decide the ultimate issue of federal recognition, ${ }^{18 \cdot 1}$ when confronted with the tension between procedural and substantive fairness, the court chose the latter.

\section{THE FUTURE OF FEDERAL RECOGNITION LITIGATION}

The recent decisions regarding the Muwekma and MWTC provide new hope for nonrecognized tribes seeking judicial assistance in their struggle for federal recognition. Although judicial precedent once suggested that nonrecognized tribes and their advocates should avoid the costly alternative of litigation, Muwekma and Mashpee suggest otherwise. When considering whether or not to bring judicial action, advocates for nonrecognized tribes should also consider the extrajudicial effects and congressional interest created by the Muwekma and Mashpee decisions.

\section{A. Extrajudicial Effects}

Successful lawsuits provide advantages and rewards that exceed the sum of legal and equitable relief. These extrajudicial effects grant plaintiffs greater power in structuring dealings and negotiations with their opponents outside the courtroom.

\section{Retaining Jurisdiction, Repeat Players, and Shaming}

The first extrajudicial effect provided by the current tribal recognition litigation results from the court's decision to retain jurisdiction. By forcing the DOI to remain accountable to the district court, the judiciary interferes with the Department's ability to become an "entrenched bureaucracy," accountable to no one. "When jurisdiction is retained and DOI officials are required to submit proposals and make final determinations within a particular timeframe, the DOI does not have the ability to ignore court orders.

${ }^{183}$ See id. at 135 (noting the tribe's uncontested assertion that "the delay in processing their petition directly affects the rights, health, and welfare of the Tribe and its members").

${ }^{184}$ See id. at 132 ("The authority to determine the eligibility of tribes for federal recognition is assigned to the BIA.").

See ROSENBERG, supra note 113, at 23 (discussing "entrenched bureaucracies" as "self-perpetuating, self-sufficient bureaus which are power sources un to themselves"). 
It is also significant that the District of Columbia federal courts have required the DOI to meet its obligations to Indian tribes. ${ }^{186}$ The DOI is a "repeat player" ${ }^{187}$ in the D.C. Circuit and therefore has an incentive to comply with the court's ruling. ${ }^{1 \times 8}$ The next time the Department is before the court on another matter may be within weeks of the original decision, rather than years in other federal jurisdictions.

Given the proximity and relationship between governmental agencies and the D.C. Circuit, the DOI is more vulnerable to the court's discussion of their behavior. Professors Edward Rock and David Skeel have noted the use of shaming in Delaware fiduciary law to enforce norms of appropriate corporate behavior. ${ }^{189}$ Likewise, in the context of administrative law, judicial censure by D.C. federal courts affects the attitude and vigor with which the Department applies the United States' fiduciary duty to Native Americans.

\section{Bargaining in the Shadow of the Law}

Scholars have noted the use of judicial decisions as "bargaining chips" in dealings between parties outside of the courtroom. ${ }^{190}$ Once nonrecognized tribes have won in court, the rights vindicated by litigation become the "possessions of the dispossessed": tribe to use in negotiations with the DOI. As Professor Michael McCann has noted, "judicial proclamations are likely to have less impact in altering the tion).

${ }^{181 ;}$ See supra Part III.B (considering the success of the Mutvekma and Mashpee litiga-

${ }^{187}$ See Marc Galanter, Why the "Haves" Come out Ahead: Speculation About the Limits of Legal Change, 9 L.AW \& SOC'Y REv. 95, 97 (1974) (defining repeat players as parties "who are engaged in many similar litigations over time").

${ }^{168}$ See id. at 99-10I (noting that preserving a repeat player's "bargaining reputation" that she obeys the rules is more important than winning or losing any individual case).

18: See Edward B. Rock, Saints and Sinners: How Does Delaware Corporate Law Work?, 44 UCLA L. REV. 1009, 1106 (1997) (concluding that Delaware fiduciary law functions "as a set of parables or folktales of good and bad managers and directors" constraining fiduciaries' duties to the corporation); David A. Skeel, Jr., Shaming in Corporate Law, 149 U. PA. L. REV. 1811, 1811-13 (2001) (arguing that the importance of one's reputation in the corporate context renders shaming an effective method of distinguishing impermissible from permissible behavior).

1910 See Robert H. Mnookin \& Lewis Kornhauser, Bargaining in the Shadow of the Law: The Case of Divorce, 88 YALE L.J. 950, 968 (1979) (observing that "the outcome that the law will impose if no agreement is needed" provides a powerful incentive for extrajudicial resolution of disputes).

191 Martha MinOW, Making All the Difference: INCLUSION, EXClusion, AND AMERICAN LAW 310 (1990). 
substantive values of most citizens ... than in reshaping perceptions of when and how particular values are realistically actionable as claims of legal right."1:2 In the wake of Muzvekma and Mashpee, nonrecognized tribes who have submitted their documentation have the power to force the DOI to meet their obligations, and can use their viable litigation option as a bargaining chip in negotiations with the DOI.

Appreciating this "constitutive capacity of law"1:3 permits a deeper understanding of the impact of judicial decisions. When assessing the weight and effect of judicial measures, it is important to consider not only whether a particular party won or lost, but how other similarly situated actors may appropriate the judicial decision to their benefit.

\section{B. The Impact of the Muwekma and Mashpee Litigation}

Though it is difficult to measure the impact of the Muwekma and Mashpee decisions on the field of federal Indian recognition, there is some indication that the DOI is experiencing the consequences. One indication is the Department's unsuccessful appeal for deadline extensions in Muwekma III. ${ }^{194}$ Arguably, if the Department had the capability to fulfill its fiduciary obligation to the nonrecognized tribes, it likely would have done so. The Department has been unable to meet ihis obligation, however, and instead may now have to pursue bureaucratic reorganization. In fact, the Department may be so incapable of deciding recognition petitions within twelve months that it would be willing to forfeit this responsibility altogether.

Since 1992, the Native American Oversight Committees of both the House of Representatives and the Senate have discussed transferring the federal acknowledgment process from the DOI to a separate congressional commission. ${ }^{195}$ In 1994, Congressman Craig Thomas from Wyoming introduced H.R. 4462, which would establish a "Commission on Indian Recognition" to oversee the acknowledgment process. ${ }^{1 ! 6}$ Expressing confidence that problems in the federal recognition process could be resolved by the DOI, officials vehemently opposed

\footnotetext{
(1993)

IId. at 733 .

194 Supra note 178 and accompanying text.

11:5e Hearing on H.R. 3430, supra note 26, at 58 (statement of Henry J. Sockbeson, Attorney, Native American Rights Fund) (suggesting that the recognition process "be taken out of [DOI]" and transferred to Congress).

${ }^{196}$ Hearing on Federal Regulation of Indian Tribes, supra note 73, at 78-79 (statement of Rep. Craig Thomas, Member, House Comm, on Natural Res.).
}

${ }^{192}$ Michael W. McCann, Reform Litigation on Trial, 17 LAW \& SOC. INQUIRY 715, 732 
the removal of the FAP from the Department's jurisdiction. ${ }^{197}$ However, in 2000, the DOI suddenly admitted its incapacity to efficiently decide nonrecognized tribes' petitions. ${ }^{1 ! k}$ During the hearings, the Department's representative, Kevin Gover, testified that "even after our best efforts... . we are not going to be able to do better than we have for the last few years." Gover feared that federal recognition would "never become a priority of any future Administration" ${ }^{200}$ leading him to "encourage the [C]ommittee to mark up [the] bill and work on it." The Department's change of heart arguably might be the result of congressional pressure, but this does not entirely account for the change, particularly since the process has been subject to congressional oversight since its inception. More likely, however, the combination of congressional pressure and federal recognition litigation encouraged the DOI to honestly evaluate its limitations.

\section{CONCLUSION}

Nonrecognized tribes entered the litigation process hopeful that the federal judiciary would look past matters of formal legalism to help remedy the struggles Indians face to achieve recognition through the FAP. In the majority of judicial decisions, the courts proved unwilling or incapable of honoring the historical promises made to nonrecognized tribes. Recent decisions, however, suggest that the litigation efforts of nonrecognized tribes may not have been in vain. The successful mandamus actions of the Muwekma and Mashpee Tribes provide new promise for nonrecognized tribes' dreams of inclusion in the recognized Indian community.

197 See id. at 107 (statement of Patrick A. Hayes, Acting Deputy Comm'r of Indian Affairs, United States Dep't' of the Interior) (opposing H.R. 4462 because of the Department's particular expertise in Indian Affairs and his confidence that recent regulations would solve prior difficulties).

19: See Federal Recognition: Hearing on S. 611 to Provide for Administrative Procedures to Extend Federal Recognition to Certain Indian Groups, 106th Cong. 54-55 (2000) (statement of Kevin Gover, Assistant Sec'y of Indian Affairs, United States Dep't of the Interior) (stating that the DOI has made insufficient progress in processing recognition applications).
ld. at 54 .
200 ld.
201 Ih. at 55 . 